\title{
Evaluation of the Knowledge and Attitude Changes of Mothers in Neonatal Care
}

\section{Annelerin Yenidoğan Bakımında Bilgi ve Tutum Değișimlerinin Değerlendirilmesi}

\author{
Şahin Hamilçıkan', Yeliz Polat², Emrah Can'1, Meltem Erol², Özlem Bostan Gayret², Özgül Yiğit² \\ 2University of Health Sciences, Bağcllar Training and Research Hospital, Neonatal Intensive Care Unit, Istanbul, Turkey \\ 'University of Health Sciences, Bağcllar Training and Research Hospital, Clinic of Pediatrics, Istanbul, Turkey
}

\begin{abstract}
Aim: The aim was to determine the initial knowledge of mothers about neonatal care and evaluate their knowledge, care and attitude changes following individual education.

Materials and Methods: Questionnaire forms designed on the subject of infant care and nutrition were given to mothers right after delivery. Before being discharged they were informed by the doctor and breastfeeding nurse about nutrition, infant care, and the most common mistakes. These forms were reapplied on the $15^{\text {th }}$ and $30^{\text {th }}$ days in neonatal polyclinic controls and the changes were evaluated. The correct information was repeated to the mothers who were detected to have misinformation and wrong attitudes in the evaluations in each form application period.

Results: A total of 100 mothers and their infants were included in the study. No difference was determined in the nutrition rates of infants with food other than breast milk on the first day, $15^{\text {th }}$ and $30^{\text {th }}$ days. However, the breastfeeding rates obtained were higher on the $30^{\text {th }}$ day than on the $15^{\text {th }}$, with an interval of two hours, and in general breastfeeding rates were low on the $15^{\text {th }}$ and $30^{\text {th }}$ days. The rates of bathing the infants with and without a bathtub net were determined to be high on the $15^{\text {th }}$ and $30^{\text {th }}$ days. The change in the infants' sleeping positions, the place of sleep, and the presence of rails/guards around the crib on the $15^{\text {th }}$ and $30^{\text {th }}$ days were not found to be significant compared to the $1^{\text {st }}$ day. There was a significant increase in the umbilical care rates on the $15^{\text {th }}$ and $30^{\text {th }}$ days. The increase in washing the clothes of the infants with soap powder, and the decrease in swaddling after the education were found to be significant. Furthermore, it was determined that the mothers received infant care information more frequently from the healthcare organisation
\end{abstract}

ÖZ

Amaç: Annelerin yenidoğan bakımı hakkında ilk bilgilerinin saptanması ve bireysel eğitim sonrası bilgi, bakım ve tutum değişimlerinin değerlendirilmesi amaçlanmıştır.

Gereç ve Yöntemler: Doğum yapan annelere doğumdan hemen sonra yenidoğan bebeklerin bakımı ve beslenmesi konusunda düzenlenen anket formları verildi. Anneler taburcu olmadan önce doktor ve emzirme hemşiresi tarafından beslenme, bebek bakımı ve en sık yapılan yanış̦lar konusunda bilgilendirildi. Yenidoğan polikliniği kontrollerinde bu formlar 15-30. günlerde tekrar uygulanarak aradaki değişim değerlendirildi. Değerlendirmelerde yanlış bilgi ve tutum saptanan annelere doğru bilgiler her form uygulama döneminde yinelendi.

Bulgular: Çalışmaya toplam 100 anne ve bebeği dahil edildi. Bebeklerin ilk gün, 15. gün ve 30 . gün anne sütü harici gıda ile beslenme oranlarında fark saptanmadı. Ancak bebeklerin 30. günde, 15. güne göre iki saat ara ile emzirme oranları daha yüksek; genel olarak anne sütü ile beslenme oranları ise 15. gün ve 30 . günde düşük olarak elde edildi. Bebeklerin 15. günde ve 30 . günde banyo yapma oranı ve file üzerinde banyo yapma oranları yüksek tespit edildi. Bebeklerin ilk güne göre 15. gün ve 30. günlerde uyku pozisyonları, uyudukları yer ve beşikte parmaklık/ koruyucularının olma oranlarındaki değişim anlamlı bulunmadı. Göbek bakımı yapma oranlarında artış 15. gün ve 30 . gün için anlamlı bulundu. Eğitim sonrası bebek kıyafetlerinin sabun tozu ile yıkanmasındaki yükseliş ve bebeklere kundak yapılmasındaki düşüş anlamlı olarak bulundu. Ayrıca annelerin ilk güne göre 15. gün ve 30 . günlerde bebek bakım bilgilerini daha yüksek sıklıkta sağlık kuruluşundan aldıkları tespit

\section{Address for Correspondence/Yazıșa Adresi}

Emrah Can MD, University of Sciences Bağcllar Training and Research Hospital, Neonatal Intensive Care Unit, Istanbul, Turkey

Phone: +90 5325123606 E-mail: canemrahcan@yahoo.com

Received/Geliş tarihi: 06.12.2016 Accepted/Kabul tarihi: 10.01.2017

${ }^{\circ}$ Copyright 2017 by Ege University and Ege Children's Foundation

The Journal of Pediatric Research, published by Galenos Yayınevi. 
on the $15^{\text {th }}$ and $30^{\text {th }}$ days compared to the $1^{\text {st }}$ day. The highest correlation between the maternal education level and the post-education knowledge and attitude change was determined in uneducated and primary school graduate mothers $\left(r^{2}=0.35\right)$.

Conclusion: The frequency and duration of the breastfeeding, infant umbilical care, swaddling, bathing, sensitivity to pinning jewellery on the infants, and whether or not mothers receive information about infant care from a healthcare organisation have changed positively after the education.

Keywords: Neonatal care, breast milk, maternal education edildi. Annelerin eğitim düzeyleri ile eğitim sonrası bilgi ve davranış değişikliği arasında en yüksek ilişki, eğitimsiz ve ilkokul mezunu olan annelerde saptandı $\left(r^{2}=0,35\right)$.

Sonuç: Annelerin yenidoğan bebeklerini emzirme sıklı̆ı ve süresi, bebeklerin göbek bakımı, kundak yapma, bebeklerini yıkama, bebeklere takı takma hassasiyeti, bebek bakımı hakkında bilgileri sağlık kuruluşundan alma durumları eğitim sonrası olumlu yönde değişmektedir.

Anahtar Kelimeler: Yenidoğan bakımı, anne sütü, anne eğitimi

\section{Introduction}

When parents decide to have a baby, the first evaluation of the parents' health should be performed by specialists in the pre-pregnancy period, and this observation and informing should be continued after the pregnancy. Health promotion is defined as activities that help an individual to improve resources that maintain and increase the well-being of the individual (1)

Various education and counselling programs are offered at different times to ensure that pregnancy, delivery, and postnatal period are spent healthfully in terms of the mother and the baby. In these programs, the late prenatal classes begin in the third trimester of pregnancy, and the expectant parents are trained on the subjects of delivery, infant care and infant nutrition (2).

In this study, we aimed to determine the levels of knowledge on newborn nutrition and care of the mothers whose infants were born through normal spontaneous vaginal delivery or cesarean section at Bağcılar Training and Research Hospital, and to evaluate the change in these knowledge levels with education.

\section{Materials and Methods}

The study was conducted as a cross-sectional study with mothers, and their infants born at Bağcılar Training and Research Hospital, Obstetric Unit between January 2016 and September 2016. Questionnaire forms designed on the subject of infant nutrition, infant care, and traditional practices were given to mothers right after delivery. The questionnaire forms included questions about the educational levels of the mothers, time of the first breastfeeding, nutrition type and frequency, form of nutrition other than breastfeeding, the first bathing time and place, umbilical care, infant sleeping patterns, attitudes towards traditional practices (jewellery, pacifier, putting infant to sleep with a blanket covering its face, swaddling); and information acquisition resources were addressed to the mothers and situation determination was done. The mothers' information was evaluated by a doctor and breastfeeding nurse after the questionnaire and the mothers were informed about nutrition, infant care, and traditional practices. The questionnaire forms were repeated on the $15^{\text {th }}$ and $30^{\text {th }}$ days in the neonatal policlinic controls and the changes were evaluated. Mothers who were determined to have wrong information and attitudes in the evaluations were supplied with the correct forms after the application.

The ethical approval of the study was obtained from the hospital ethics committee (approval number: 2016-12). Written consent was obtained from the mothers before the study.

\section{Statistical Analysis}

Number Cruncher Statistical System (NCSS) 2007 (Kaysville, Utah, USA) program was used for statistical analyses. Descriptive statistical variables were used for quantitative variables in the study data. The Friedman test was used for the evaluations and comparisons between the variables and the Wilcoxon signed-rank test and the Spearman correlation test were used in paired evaluations. The level of $p<0.05$ was accepted to be significant.

\section{Results}

A total of 100 mothers and their infants were included in the study. $47 \%$ of the infants included in the study were born via cesarean section, and $53 \%$ through normal vaginal delivery. $52 \%$ of the cases were boys and $48 \%$ were girls. The educational levels of the mothers, the time of the first breastfeeding, the delivery method, and the gender of the infants are presented in Table I. No difference was determined in the nutrition rates of the infants with food other than breast milk on the first day, $15^{\text {th }}$ and $30^{\text {th }}$ days. However, the breastfeeding rates of the infants were higher on the $30^{\text {th }}$ day than on the $15^{\text {th }}$ day, with an interval of two 
hours, and in general, breastfeeding rates obtained on the $15^{\text {th }}$ and $30^{\text {th }}$ days were low.

The rates of bathing the infants with and without a bathtub net were determined to be high on the $15^{\text {th }}$ and $30^{\text {th }}$ days. The change in the sleeping positions of the infants, the place of sleep, and the presence of rails/guards around

\begin{tabular}{|l|l|l|l|}
\hline Table I. Distribution of descriptive characteristics \\
\hline \multirow{4}{*}{ Method of delivery } & & $\mathbf{n}$ & $\%$ \\
\hline Gender & Vaginal & 53 & 53.0 \\
\cline { 2 - 4 } & Cesarean section & 47 & 47.0 \\
\hline \multirow{4}{*}{ Maternal educational level } & Female & 48 & 48 \\
\hline \multirow{5}{*}{$\begin{array}{l}\text { Time of the first breastfeeding } \\
\text { of the infant }\end{array}$} & Male & 52 & 52 \\
\cline { 2 - 4 } & Illiterate & 17 & 17.0 \\
\cline { 2 - 4 } & Primary school & 27 & 27.0 \\
\cline { 2 - 4 } & Secondary school & 36 & 36.0 \\
\cline { 2 - 4 } & High school & 13 & 13.0 \\
\cline { 2 - 4 } & University & 7 & 7.0 \\
\cline { 2 - 4 } & Did not breastfeed & 5 & 5.0 \\
\cline { 2 - 4 } & 30 minutes & 30 & 30.0 \\
\cline { 2 - 4 } & 1 hour & 40 & 40.0 \\
\cline { 2 - 4 } & 2 hours and more & 25 & 25.0 \\
\hline
\end{tabular}

the crib on the $15^{\text {th }}$ day and the $30^{\text {th }}$ day was not found to be significant compared to the first day. The increase in the rates of sleeping in the dark after receiving the education was significant as well as the increase in the umbilical care rates on the $15^{\text {th }}$ and $30^{\text {th }}$ days in comparison to the first day. The results regarding the form of nutrition other than breastfeeding, the first bath, sleeping position, place and environment of sleep and umbilical care of the infants are presented in Table II.

No significant change was determined on the $15^{\text {th }}$ and $30^{\text {th }}$ days compared to the first day in the diaper changing tools for infants, pacifier use and its reasons, and in the evaluation of covering the face while sleeping and the reasons for covering the face. After the education, the increase in washing the clothes of the infant with soap powder, and the decrease in swaddling were found to be significant. No change was determined in the rates of pinning jewellery to the infants' clothes after the education. Furthermore, a significant increase was determined in the rates of mothers receiving infant care information from the healthcare organisation on the $15^{\text {th }}$ and $30^{\text {th }}$ days compared to the first day (Table III).

The highest correlation between maternal educational levels and post-education knowledge, and attitude and

Table II. Evaluations for breastfeeding, bathing and umbilical care

\begin{tabular}{|c|c|c|c|c|c|c|c|}
\hline & \multirow{2}{*}{$\begin{array}{l}1^{\text {st }} \text { day } \\
n(\%)\end{array}$} & \multirow{2}{*}{$\begin{array}{l}15^{\text {th }} \text { day } \\
n(\%)\end{array}$} & \multirow{2}{*}{\begin{tabular}{|l}
$30^{\text {th }}$ day \\
n (\%) \\
\end{tabular}} & \multirow[t]{2}{*}{$\mathrm{p}$} & \multirow[b]{2}{*}{$1^{\text {st }}$ day- $15^{\text {th }}$ day } & \multirow[b]{2}{*}{$1^{\text {st }}$ day- $30^{\text {th }}$ day } & \multirow[b]{2}{*}{$15^{\text {th }}$ day-30 $0^{\text {th }}$ day } \\
\hline & & & & & & & \\
\hline \multirow[t]{2}{*}{ Form of nutrition other than breastfeeding } & $15(15.0)$ & $10(10.0)$ & $9(9.0)$ & 0.060 & 0.132 & 0.058 & 0.317 \\
\hline & $1(1.0)$ & $99(99.0)$ & $100(100)$ & 0.001 & 0.001 & 0.001 & 0.317 \\
\hline \multicolumn{8}{|l|}{ First bathing time } \\
\hline As soon as discharged from the hospital & $89(89.0)$ & $90(90.0)$ & $90(90.0)$ & 0.368 & 0.317 & 0.317 & 1.000 \\
\hline After the umbilical cord has fallen off & $11(11.0)$ & $10(10.0)$ & $10(10.0)$ & & & & \\
\hline \multicolumn{8}{|l|}{ First bathing place } \\
\hline Bathtub & $24(24.0)$ & $15(15.0)$ & $10(10.0)$ & 0.001 & 0.001 & 0.001 & 0.020 \\
\hline Plastic basin & $51(51.0)$ & $15(15.0)$ & $15(15.0)$ & & & & \\
\hline On a bathtub net & $25(25.0)$ & $70(70.0)$ & $75(75.0)$ & & & & \\
\hline \multicolumn{8}{|l|}{ Sleeping position } \\
\hline While breastfeeding & $96(96.0)$ & $96(96.0)$ & $95(95.0)$ & 0.867 & 1.000 & 0.705 & 0.317 \\
\hline Lying position & $4(4.0)$ & $4(4.0)$ & $5(5.0)$ & & & & \\
\hline \multicolumn{8}{|l|}{ Place of sleep } \\
\hline Crib & $98(98.0)$ & $99(99.0)$ & $99(99.0)$ & 0.368 & 0.317 & 0.317 & 1.000 \\
\hline No bed & $2(2.0)$ & $1(1.0)$ & $1(1.0)$ & & & & \\
\hline Rail, guard & $94(94.0)$ & $95(95.0)$ & $94(94.0)$ & 0.779 & 0.564 & 1.000 & 0.317 \\
\hline \multicolumn{8}{|l|}{ Sleeping environment } \\
\hline In the dark & $49(49.0)$ & $58(58.0)$ & $56(56.0)$ & 0.084 & 0.018 & 0.040 & 0.739 \\
\hline Illuminated & $31(31.0)$ & $26(26.0)$ & $29(29.0)$ & & & & \\
\hline Umbilical care & $27(27.0)$ & $83(83.0)$ & $52(52.0)$ & 0.001 & 0.001 & 0.001 & 0.001 \\
\hline
\end{tabular}


Table III. Evaluation of primary care and traditional practices

\begin{tabular}{|c|c|c|c|c|c|c|c|}
\hline & \multirow{2}{*}{$\begin{array}{l}1^{\text {st }} \text { day } \\
n(\%)\end{array}$} & \multirow{2}{*}{$\begin{array}{l}15^{\text {th }} \text { day } \\
n(\%)\end{array}$} & \multirow{2}{*}{$\begin{array}{l}30^{\text {th }} \text { day } \\
\mathrm{n}(\%)\end{array}$} & \multirow[t]{2}{*}{ p } & \multirow[b]{2}{*}{$1^{\text {st }}$ day- $15^{\text {th }}$ day } & \multirow[b]{2}{*}{$1^{\text {st }}$ day- $30^{\text {th }}$ day } & \multirow[b]{2}{*}{$15^{\text {th }}$ day- $30^{\text {th }}$ day } \\
\hline & & & & & & & \\
\hline \multicolumn{8}{|l|}{ Diaper changing tool } \\
\hline Wet wipes & $90(90.0)$ & $89(89.0)$ & $88(88.0)$ & 0.607 & 0.783 & 0.589 & 0.317 \\
\hline Wet cotton & $6(6.0)$ & $7(7.0)$ & $8(8.0)$ & & & & \\
\hline Washing & $4(4.0)$ & $4(4.0)$ & $4(4.0)$ & & & & \\
\hline \multicolumn{8}{|l|}{ Cleaning of clothes } \\
\hline Soap powder & $58(58.0)$ & $71(71.0)$ & $73(73.0)$ & 0.001 & 0.001 & 0.001 & 0.157 \\
\hline Detergent & $42(42.0)$ & $29(29.0)$ & $27(27.0)$ & & & & \\
\hline Pacifier use & $53(53.0)$ & $55(55.0)$ & $55(55.0)$ & 0.135 & 0.157 & 0.157 & 1.000 \\
\hline \multicolumn{8}{|l|}{ Reason for pacifier use } \\
\hline Sleep & $6(11.3)$ & $7(12.7)$ & $7(12.7)$ & 0.368 & 0.180 & 0.257 & 1.000 \\
\hline Crying & 37 (69.8) & $40(72.7)$ & 40 (72.7) & & & & \\
\hline Does not know & $10(18.9)$ & $8(14.5)$ & $8(14.5)$ & & & & \\
\hline Swaddling & $39(39.0)$ & $16(16.0)$ & $11(11.0)$ & 0.001 & 0.001 & 0.001 & 0.025 \\
\hline \multicolumn{8}{|l|}{ Reason for swaddling } \\
\hline Culture & $13(33.3)$ & $9(56.3)$ & $5(45.5)$ & - & 1.000 & 1.000 & 1.000 \\
\hline To make baby stay still & $26(66.7)$ & $7(43.8)$ & $6(54.5)$ & & & & \\
\hline Pinning jewellery & $3(3.0)$ & $3(3.0)$ & $4(4.0)$ & 0.717 & 1.000 & 0.564 & 0.564 \\
\hline The use of face cover & $71(71.0)$ & $68(68.0)$ & $65(65.0)$ & 0.034 & 0.180 & 0.034 & 0.083 \\
\hline \multicolumn{8}{|c|}{ Reason for covering the face } \\
\hline Family education & $5(7.0)$ & $3(4.4)$ & $3(4.6)$ & 0.135 & 0.180 & 0.180 & 1.000 \\
\hline Prevention of jaundice & $22(31.0)$ & $20(29.4)$ & $20(30.8)$ & & & & \\
\hline Prevention of dust & $18(25.4)$ & $19(27.9)$ & $18(27.7)$ & & & & \\
\hline Prevention of light & $26(36.6)$ & $26(38.2)$ & $24(36.9)$ & & & & \\
\hline \multicolumn{8}{|l|}{ Receiving care information } \\
\hline Family & $92(92.0)$ & $49(49.0)$ & $38(38.0)$ & 0.001 & 0.001 & 0.001 & 0.001 \\
\hline Internet & $1(1.0)$ & $0(0)$ & $0(0)$ & & & & \\
\hline Healthcare organization & $7(7.0)$ & $51(51.0)$ & $62(62.0)$ & & & & \\
\hline
\end{tabular}

behaviour change was seen in uneducated and primary school graduate mothers $\left(r^{2}=0.35\right)$.

\section{Discussion}

A mother's maternal role, acceptance of her baby and acquisition of the necessary knowledge and care skills as of the pre-pregnancy period, during pregnancy and after delivery, and performing the care of the infant with proper practices are very important for neonatal and maternal health. While emphasising the importance of education and information, the evaluation of this especially during the postpartum period, and the improvement of the knowledge and attitude by providing the necessary feedback should be one of the primary duties of neonatal health centres (3-5).

The level of education can create a number of differences, especially in reaching the information and in the process of using it. According to the Turkey Demographic and Health Survey 2013 (TDHS-2013), the mothers' education rates were reported as follows: $11.8 \%$ of mothers were uneducated, $32.3 \%$ were primary school graduates, $25 \%$ secondary school graduates, and $30.9 \%$ were high school and higher education graduates (6). In our study, the ratio of uneducated mothers was $17 \%$, primary school graduates $27 \%$, secondary school graduates $36 \%$, and high school and higher education graduates was $20 \%$. These ratios seem to be consistent with the averages in our country. Our study revealed that mostly primary school graduates and uneducated mothers benefited from the education provided to them. These results suggest that mothers have little experience in infant care, mothers with low educational levels are more sensitive to the education provided, and they can develop their attitudes and behaviors in a positive way rapidly. As the educational level increases, individual 
information acquisition increases, and new information and practices cannot be accepted readily.

All mothers need information about infant care, but especially those who are going through their first pregnancies have been determined to have more difficulties in infant care and need information on various topics regarding the care of babies (7). This lack of information can be valid both for the mother's self-care and her infant (8). It is reported that in the postpartum period, mothers often receive information from their friends and relatives, and infant nutrition takes the first place among maternal concerns $(8,9)$.

Breastfeeding is a significant contributor in terms of the cost for mother and infant, health promoter and disease preventer (9). The UNICEF and World Health Organization emphasise the vital importance of breast milk by stating that breastfeeding the infant within the first hour after birth prevents $22 \%$ of neonatal deaths, and within the first day prevents $16 \%$ (6). In our study, it was determined that mothers were willing to breastfeed their infants in the first days but there was generally a decrease in the rates of feeding only with breast milk in the following days despite the provided education and that mothers fed their infants with food other than breast milk. The first feeding time and intake of colostrum by the infant are very important and therefore it is recommended that the infant is given breast milk within the first 30 minutes, especially in the case of vaginal delivery. According to the TDHS-2013 data, $50 \%$ of the infants are breastfed within the first hour after birth. In our study, the ratio of starting breastfeeding is $30 \%$ in the first 30 minutes and $40 \%$ in the first hour. These data are generally above the country average. This difference can be explained by the fact that our hospital is a baby-friendly hospital and the personnel receive training on encouraging mothers to breastfeed.

It has been observed that mothers apply wrong practices, and neonates are deprived of breast milk in cases when no education is provided on subjects such as the benefits of breast milk, and breastfeeding technique before delivery, and mothers are not encouraged to breastfeed after delivery (10). In the TDHS-2013 data, 27\% of infants were not breastfed in the first 24 hours after birth (6). In our study, this rate was determined as $5 \%$.

Infants can be bathed two or three times a week. The water temperature can be checked by inserting the elbow into the water. The infant should be held from his chest and washed face down. Also, the infant can be washed on a bathtub net vertically in the bath (11). In our study, the accuracy of washing habits in the evaluations on the $15^{\text {th }}$ and $30^{\text {th }}$ days following the first interview with family members show that the education has been successful.
The infant should be laid down in a crib or a cot on a flat surface. The room temperature should be kept between 21 and $24{ }^{\circ} \mathrm{C}$. There should be no pillow and the bed sheet should be stretched (11). In our study, it was found that the mothers put their infants to sleep while breastfeeding, and in a crib with rails, and in the dark. These results suggested that infants slept in a proper environment and that the mothers' consciousness of putting infants to sleep in the dark increased after the training.

Infection can be prevented by keeping the umbilical cord clean and dry, without applying anything, and this can help the umbilicus to fall off early $(11,12)$. Furthermore, diapers should be fastened below the umbilical cord so that it will not be in contact with urine and faeces. It was determined that in the conditions of our country, umbilical care with only sterile gauze is sufficient in healthy neonates (13). In our study, after the first interview with the mothers, dry care was recommended for umbilical care, and there was a positive change after the training.

Due to the sensitivity of the neonatal skin, irritation or rash may occur as a result of contact with faeces and urine for a long time. To prevent this, it is important to wipe off, or wash and dry the infant every time he wets his diaper. A baby girl's bottom must be wiped from front to back in order to prevent infections because of the shortness of the urethra in baby girls (14). In the study, it was determined that nearly all of the mothers obtained the correct information about neonatal bottom care after the education. This issue is very important for protection against future urinary tract infections and diaper dermatitis.

It is also important that baby clothes have cotton content, and some issues should be taken into consideration when washing clothes. It is known that soap powder is less allergenic than detergents, and this is important in terms of atopic dermatitis (15). In our study, it was determined that the mothers washed the baby clothes mainly with soap powder and that these tendencies increased even more on the $15^{\text {th }}$ and $30^{\text {th }}$ days.

Negative results have been reported on the use of a pacifier in the studies conducted. According to these, infants are reported to have decreased sucking durations due to breast confusion created after using the pacifier (16). The rate of pacifier use was $55 \%$ in our study, and despite the education provided, this rate did not change and the mothers continued to use pacifiers to prevent their babies from crying.

Swaddling still continues as a tradition in some regions of our country. However, it has been reported that swaddling an infant may be associated with congenital hip dysplasia (11). In a study conducted, $64 \%$ of the women said that they 
swaddled their infants 30 minutes after delivery (17). In our study, while $39 \%$ of the mothers said that they swaddled their infants on the first day, this ratio regressed to $16 \%$ on the $15^{\text {th }}$ day and to $11 \%$ on the $30^{\text {th }}$ day, with the education provided.

The rate of mothers pinning evil eye pendants with a safety pin to their infants' clothes to protect them from the evil eye is $25 \%$ in our country (18). The rate of this cultural practice was found to be around $4 \%$ in our study.

It is known that mothers adopt various methods to put their infants to sleep. One of the traditional practices is covering the face of the infant with a cheesecloth (19). Our study showed that mothers cover the face of their infants for various reasons such as putting them to sleep, protecting from dust. However, in the studies conducted, it has been reported that the infant's sleeping with his face covered is associated with sudden infant death syndrome $(20,21)$. In our study, it was determined that this behaviour did not change despite the maternal education provided.

In a study covering eight provinces in our country, it was found out that $54.8 \%$ of the women acquired information about self-care and infant care from the elder members of the family, and only $16 \%$ of the women received help from healthcare personnel. This shows that women in our country cannot sufficiently benefit from health services in infant health in the postpartum period (22). In our study, while mothers acquired infant care information from the elders in the family by $92 \%$ on the first day, on the $30^{\text {th }}$ day, with the education provided, this rate turned into receiving information from healthcare institutions by $62 \%$.

\section{Study Limitations}

There were some limitations of the study. There was limited number of mothers, the results should be confirmed with a higher number of mothers and neonates.

\section{Conclusion}

This study has shown that the frequency and duration of the breastfeeding of the neonates, infant umbilical care, swaddling, bathing of the infants, sensitivity to pinning jewellery on the infants' clothes, and the mothers' receiving information about infant care from a healthcare organisation have changed positively after the education.

\section{Ethics}

Ethics Committee Approval: The study was approved by the Bağcılar Training Research Hospital Local Ethics Committee (Approval number: 2016-12).

Informed Consent: Consent form was filled out by all participants.
Peer-review: Externally peer-reviewed.

\section{Authorship Contributions}

Surgical and Medical Practices: Ş.H., Y.P., Concept: S.H., Y.P., Design: S..H., E.C., Data Collection or Processing: S..H., E.C., M.E., Analysis or Interpretation: S..H., M.E., Ö.Y., Literature Search: S..H., Y.P., Ö.B.G., Ö.Y., Writing: S..H., E.C.

Conflict of Interest: No conflict of interest was declared by the authors.

Financial Disclosure: The authors declared that this study received no financial support.

\section{References}

1. Osrin D, Tumbahangphe KM, Shrestha $D$, et al. Cross sectional, community based study of care of newborn infants in Nepal. BMJ 2002;325:1063.

2. Gökdemirel S, Yusuf S. Doğum Öncesi Eğitim Programı. [Prenatal Education Program], II. Ulusal Ana Çocuk Sağlığı Kongre Kitabı, İstanbul Üniversitesi, İstanbul, 2003. p. 43-5.

3. Taşkın L. Doğum ve Kadın Sağlığı Hemşireliği [Obstetric and Women's Health Nursing], (Geliştirilmiş VI. Baskı). Sistem Ofset Matbaaclık, Ankara 2003. p. 365-75.

4. Ekizler H. Perinatal Dönemde Anne ve Çocuk Sağlığının Sürdürülmesi, Geliştirilmesi ve Değerlendirilmesi. Hemşirelik Bülteni, 1996. p. 5-13.

5. Vural G, Akan N. Annelerin Doğum Sonu Dönemde Ev Ortamında Kendi Bakımları ve Bebek Bakımı ile Ilgili Karşılaștıkları Sorunlar ve Bu Sorunlara Yönelik Uygulamalar. Hacettepe Üniversitesi Hemşirelik Yüksekokulu Dergisi 1995;2:37-49.

6. Sağlık Bakanlığı (Türkiye), Hacettepe Üniversitesi Nüfus Etütleri Enstitüsü, Türkiye Nüfus ve Sağlık Araştırması 2013 [Ministry of Health (Turkey), Hacettepe University Institute of Population Studies, Turkey Demographic and Health Survey 2013], Ankara, 2014.

7. Başer M, Mucuk S, Korkmaz Z, Seviğ Ü. Postpartum Dönemde Anne ve Babaların Yenidoğan Bakımına Illişkin Gereksinimlerinin Belirlenmesi. Sağlık Bilimleri Dergisi 2005;14:54-8.

8. Brown SG, Johnson BT. Enhancing early discharge with home follow-up: a pilot project. J Obstet Gynecol Neonatal Nurs 1998;27:33-8.

9. Graef P, McGhee K, Rozycki J, et al. Postpartum concerns of breastfeeding mothers. J Nurse Midwifery 1988;33:62-6.

10. Samlı G, Kara B, Ünalan PC, Samlı B, Sarper N, Gökalp AS. Annelerin emzirme ve süt çocuğu beslenmesi konusundaki bilgi, inanıs ve uygulamaları: niteliksel bir araștırma Marmara Med J 2006;19:13-20.

11. Vatandaş NŞ. Bebek bakımında aileye öneriler. Sürekli Tıp Eğitimi Dergisi (STED) 2004;13:1-6.

12. Janssen PA, Selwood BL, Dobson SR, Peacock D, Thiessen PN. To dye or not to dye: a randomized, clinical trial of a triple dye/alcohol regime versus dry cord care. Pediatrics 2003;111:15-20 
13. Kul M, Gürsel O, Gülgün M, Kesik V, Sarıcı SÜ, Alpay F. Sağlıklı term yenidoğanlarda farklı göbek bakımı uygulamalarının göbek düşme zamanı ve diğer klinik sonuçlar üzerine etkilerinin değerlendirilmesi. Turk Pediatri Ars 2005;40: 22731.

14. Canadian Paediatric Society. Skin care for your baby. Paediatr Child Health 2007;12:245-7.

15. Giniş T. Çocuklarda Atopik Dermatit. Çocuk Dergisi 2009;9:62-7.

16. Benis MM. Are pacifiers associated with early weaning from breastfeeding? Adv Neonatal Care 2002;2:259-66.

17. Osrin $D$, Tumbahangphe KM, Shrestha $D$, et al. Cross sectional, community based study of care of newborn infants in Nepal. BMJ 2002;325:1063.

18. Bölükbaş N, Erbil N, Altunbaş H, Arslan Z. 0-12 aylık bebeği olan annelerin çocuk bakımında başvurdukları geleneksel uygulamalar. İnsan Bilimleri Dergisi 2009;1:164-76.

19. Anuntaseree W, Mo-Suwan L, Vasiknanonte P, Kuasirikul S, Ma-A-Lee A, Choprapawon C. Factors associated with bed-sharing and sleep position in Thai neonates. Child Care Health Dev 2008;34:482-90.

20. Zotter H, Kerbl R, Schwantzer G, Kurz R, Einspieler C. Sudden infant death syndrome risk questionnaire: a mirror of parental awareness rather than prospective diagnostic tool. Acta Paediatr 2004;93:255-7.

21. Alm B, Lagercrantz $H$, Wennergren G. Stop SIDS sleeping solitary supine, sucking soother, stopping smoking substitutes. Acta Paediatr 2006;95:260-2.

22. Şenses M, Yıldızoğlu I. Sekiz ayrı ildeki kaynana ve gelinlerin loğusalık ve çocuk bakımında geleneksel uygulamaları". Çocuk Forumu Dergisi 2002;5:44-8. 